\title{
Recent advances in understanding and managing
}

\section{adenomyosis [version 1; peer review: 2 approved]}

\author{
Silvia Vannuccini (iD1-3, Felice Petraglia3,4 \\ ${ }^{1}$ Department of Neuroscience, Psychology, Pharmacology and Child Health (NEUROFARBA), University of Florence, Florence, Largo \\ Brambilla 3, 50134, Italy \\ ${ }^{2}$ Department of Molecular and Developmental Medicine, University of Siena, Siena, viale Mario Bracci 16, 53100, Italy \\ 3Obstetrics and Gynecology, Department of Maternity and Child Health, University Hospital Florence, Careggi University Hospital, \\ Florence, Largo Brambilla 3, 50134, Italy \\ ${ }^{4}$ Department of Experimental, Clinical and Biomedical Sciences, University of Florence, Florence, Largo Brambilla 3, 50134, Italy
}

V1 First published: 13 Mar 2019, 8(F1000 Faculty Rev):283

https://doi.org/10.12688/f1000research.17242.1

Latest published: 13 Mar 2019, 8(F1000 Faculty Rev):283

https://doi.org/10.12688/f1000research.17242.1

\section{Abstract}

Adenomyosis is a benign uterine disorder in which endometrial glands and stroma are pathologically demonstrated in the uterine myometrium and it is considered a specific entity in the PALM-COEIN FIGO (polyp; adenomyosis; leiomyoma; malignancy and hyperplasia; coagulopathy; ovulatory dysfunction; endometrial; iatrogenic; and not yet classified - International Federation of Gynecology and Obstetrics) classification of causes of abnormal uterine bleeding (AUB). Although it has always been considered the classic condition of multiparous women over 40 years old who have pain and heavy menstrual bleeding, diagnosed at hysterectomy, the epidemiological scenario has completely changed. Adenomyosis is increasingly identified in young women with pain, AUB, infertility, or no symptoms by using imaging techniques such as transvaginal ultrasound and magnetic resonance. However, there is no agreement on the definition and classification of adenomyotic lesions from both the histopathology and the imaging point of view, and the diagnosis remains difficult and unclear. A uniform and shared reporting system needs to be implemented in order to improve our understanding on imaging features, their relationship with pathogenic theories, and their importance in terms of clinical symptoms and response to treatment. In fact, adenomyosis pathogenesis remains elusive and not a single theory can explain all of the different phenotypes of the disease. Furthermore, adenomyosis often coexists with other gynecological conditions, such as endometriosis and uterine fibroids, increasing the heterogeneity of available data. Treatment requires a lifelong management plan as the disease has a negative impact on quality of life in terms of menstrual symptoms, fertility, and pregnancy outcome and has a high risk of miscarriage and obstetric complications.

\section{Open Peer Review}

Approval Status

1

2

version 1

13 Mar 2019

Faculty Reviews are review articles written by the prestigious Members of Faculty Opinions. The articles are commissioned and peer reviewed before publication to ensure that the final, published version is comprehensive and accessible. The reviewers who approved the final version are listed with their names and affiliations.

1. Davor Jurkovic, University College Hospital, London, UK

2. Peng-Hui Wang , National Yang-Ming

University School of Medicine, Taipei, Taiwan Taipei Veterans General Hospital, Taipei,

Taiwan

Any comments on the article can be found at the end of the article. 


\section{Keywords}

abnormal uterine bleeding, adenomyosis, endometriosis, histology, hormonal treatment, infertility, magnetic resonance imaging (MRI), medical treatment, pelvic pain, pregnancy outcome, transvaginal ultrasound sonography (TVUS), uterine fibroids.

Corresponding author: Silvia Vannuccini (silvia.vannuccini@unifi.it)

Author roles: Vannuccini S: Methodology, Writing - Original Draft Preparation, Writing - Review \& Editing; Petraglia F: Supervision, Writing - Review \& Editing

Competing interests: No competing interests were disclosed.

Grant information: The author(s) declared that no grants were involved in supporting this work.

Copyright: ( 2019 Vannuccini S and Petraglia F. This is an open access article distributed under the terms of the Creative Commons Attribution License, which permits unrestricted use, distribution, and reproduction in any medium, provided the original work is properly cited.

How to cite this article: Vannuccini $S$ and Petraglia F. Recent advances in understanding and managing adenomyosis [version 1; peer review: 2 approved] F1000Research 2019, 8(F1000 Faculty Rev):283 https://doi.org/10.12688/f1000research.17242.1

First published: 13 Mar 2019, 8(F1000 Faculty Rev):283 https://doi.org/10.12688/f1000research.17242.1 


\section{Introduction}

Adenomyosis is a benign uterine disorder in which endometrial glands and stroma are pathologically demonstrated in the myometrium ${ }^{1}$. Women affected by adenomyosis may present with abnormal uterine bleeding (AUB), dysmenorrhea, dyspareunia, or infertility but one third of them are asymptomatic ${ }^{2}$. For many years, adenomyosis has remained a histopathological diagnosis made after hysterectomy in perimenopausal women with heavy menstrual bleeding (HMB) or pelvic pain ${ }^{3}$. Over the last decade, adenomyosis has also become a condition identified in young fertile-age women ${ }^{4}$ thanks to the recent advancements in imaging techniques, even though a shared definition and classification are still lacking ${ }^{5}$. Despite the improvement of diagnostic tools, the awareness of the condition is still poor. Furthermore, in some patients, adenomyosis coexists with other gynecological conditions, such as endometriosis and uterine fibroids 6 . The physio-pathological mechanisms, involving sex steroid hormone aberrations, inflammation, fibrosis, and neuroangiogenesis, are not fully understood ${ }^{7}$. Regarding the current management of adenomyosis, there are no international guidelines to follow for surgical or medical treatment of adenomyosis ${ }^{8}$ and this will be of utmost importance in the future as the disease requires a lifelong management plan, including pain and bleeding control, fertility preservation, and pregnancy outcome.

\section{Pathogenesis}

The pathogenic mechanisms involved in adenomyosis need to be fully elucidated, but in the last decade an increasing number of studies have shown that sex steroid hormone receptors, inflammatory molecules, extracellular matrix enzymes, growth factors, and neuroangiogenic factors play a major role $\mathrm{e}^{7,9,10}$.

According to the most common theory, adenomyosis results from the invagination of basalis endometrium into the myometrium through an altered or interrupted junctional zone $(\mathrm{JZ})^{7,11}$, which represents a highly specialized hormone-responsive structure located in the inner third of the myometrium ${ }^{12}$. Molecular alterations in eutopic endometrium seem to contribute to migration and survival of ectopic endometrial implants beyond the myometrial interface ${ }^{13}$. Even though alterations in apoptosis, steroid hormone responsiveness, and extracellular matrix pathways have been found in both adenomyotic lesions and eutopic endometrium, the underlying mechanisms need to be further evaluated. In addition, the role of tissue injury and repair (TIAR) as the primary mechanism for myometrial invasion has been hypothesized ${ }^{6}$. Chronic peristaltic myometrial contractions may induce continuous microtrauma to the JZ, causing inflammation which in turn promotes local increased estrogen production, inducing a vicious cycle. A positive feedback mechanism is generated, and chronic hyperperistalsis in the JZ promotes repeated cycles of autotraumatization ${ }^{14}$. Thus, the TIAR theory, stressing the importance of tissue damage to the endometrialmyometrial interface, supports the common understanding that adenomyosis is associated with multiparity, previous cesarean section, and prior uterine surgery ${ }^{11}$.
An alternative pathogenic theory of adenomyosis proposes that the disease arises de novo from metaplasia of embryonic or adult stem cell in the myometrium ${ }^{15}$. Intramyometrial embryonic pluripotent Müllerian remnants may undergo metaplastic changes in the adult uterine wall, leading to the establishment of de novo ectopic endometrial tissue within the myometrial wall, as adenomyotic foci. However, the hypothesis of adult endometrial and stromal stem cell differentiation whenever they are deposited in the myometrium after retrograde menstruation should also be taken into account ${ }^{11,16}$. Accordingly, Chapron et al. described "from outside to inside invasion" theory, hypothesizing the migration of ectopic endometrial cells from posterior endometriosis nodules into the myometrium ${ }^{17}$. This theory was supported by the high prevalence of posterior focal adenomyosis of the outer myometrium (FOAM) found in patients with deep infiltrating endometriosis (DIE) nodules in the posterior compartment, diagnosed by magnetic resonance imaging (MRI) ${ }^{17}$. After retrograde menstruation, ectopic endometrial cells may have the potential to infiltrate not only pelvic organs but also the uterine walls. Less clear is the explanation for the $50 \%$ association of anterior FOAM shown in bladder $\mathrm{DIE}^{18}$. The intraperitoneal seeding of endometrial cells after menstruation may cause invasion of the vesicouterine pouch, generating both a bladder nodule and anterior FOAM through a trans-serosa invading process. Nevertheless, the pathogenesis of adenomyosis is still unclear and cannot be understood by only a unique theory since the phenotypes are heterogeneous and not clearly defined.

\section{Epidemiology}

Historically, adenomyosis has been identified as a pathological entity from histological reports after hysterectomy. However, currently, only a small group of women undergo non-conservative surgical treatments for adenomyosis; thus, a realistic epidemiological background cannot be established from histopathology. Furthermore, the introduction of new medical compounds and surgical techniques has allowed clinicians to conservatively treat the disease. Thus, the epidemiological scenario has changed, and although the most common risk factor profile ${ }^{19}$ included age of more than 40 years, multiparity, prior cesarean section, or uterine surgery ${ }^{19,20}$, the disease is increasingly diagnosed in young women ${ }^{4}$, in infertility patients ${ }^{21}$, or in those with pain or AUB or both ${ }^{22}$. In regard to AUB, in fact, adenomyosis is considered a specific entity in the PALMCOEIN FIGO (polyp; adenomyosis; leiomyoma; malignancy and hyperplasia; coagulopathy; ovulatory dysfunction; endometrial; iatrogenic; and not yet classified - International Federation of Gynecology and Obstetrics) classification ${ }^{23,24}$ and it is strictly associated with $\mathrm{HMB}^{22}$. However, it should also be considered that one third of patients with adenomyosis are asymptomatic ${ }^{2}$. In women undergoing assisted reproductive technologies (ARTs), the prevalence of adenomyosis is $20 \%$ to $25 \%$, whereas in those with a history of endometriosis, the percentage is widely variable, ranging from $20 \%$ to $80 \%{ }^{25,26}$. Data from ultrasound units show a $20.9 \%$ prevalence of sonographic signs of adenomyosis in the general population ${ }^{27}$, whereas the figures range from 
$10 \%$ to $35 \%$ in histological reports after hysterectomy ${ }^{28,29}$. However, uniform diagnostic criteria, in both histopathology and imaging, are needed in order to standardize the diagnosis and to have reliable updated figures.

\section{Definition and diagnosis of adenomyosis Histology}

The gold standard to make the final diagnosis of adenomyosis has always been considered histological examination of hysterectomy specimens ${ }^{23}$. So, in 2009, Weiss et al. declared that adenomyosis was an incidental finding in women undergoing hysterectomy and not the source of their symptoms ${ }^{30}$. The condition is commonly described as the presence of endometrial glands and stroma located deep within the myometrium, associated with smooth muscle hyperplasia ${ }^{31}$. This is due to the invasion of myometrium by basal glands and stroma with destruction of normal myometrium architecture ${ }^{32}$. However, the frequency of adenomyosis diagnosis can range widely among different pathologists as there are no uniform criteria regarding depth of invasion and number of foci to make a diagnosis, especially when disease is not diffuse. In previous papers, an invasion more than one third thickness of the uterine myometrium has been considered to make a diagnosis, whereas in others a myometrial invasion greater than $4 \mathrm{~mm}$ was diagnostic for adenomyosis ${ }^{33-35}$. Regarding histological classification, adenomyosis is defined as focal when circumscribed nodular aggregates of endometrial glands and stroma are surrounded by normal myometrium. Conversely, an adenomyoma is identified when the ectopic endometrial tissue within the myometrium is surrounded by hypertrophic myometrium. In diffuse adenomyosis, endometrial glands and stroma are recognized throughout the myometrium.

However, the available criteria do not consider potential different morphological appearance of ectopic cells according to cellular differentiation stage and menstrual cycle or responsiveness to hormonal drugs. In addition, results from histopathological studies are biased by the fact that in those cases all women underwent a non-conservative treatment; thus, this does not represent the entire population of adenomyotic patients or all possible phenotypes.

\section{Imaging}

The development of imaging techniques, such as MRI and transvaginal ultrasonography (TVUS), has allowed clinicians to make a non-invasive diagnosis of adenomyosis in women also undergoing conservative treatments, identifying different phenotypes of the disease. After some attempts of histological classification $^{36}$, Kishi et al. (in 2012) classified adenomyosis in four subtypes according to MRI lesion localization in the inner or outer myometrium: intrinsic, extrinsic, intramural, and indeterminate $^{37}$. In 2014, Grimbizis et al. proposed a clinical histological classification system, identifying diffuse, focal, and cystic adenomyosis $^{38}$. More recently, Bazot and Daraï proposed three subtypes-internal, external adenomyosis, and adenomyomasaccording to MRI features ${ }^{39}$. However, a shared classification system has not been developed yet as further research is needed in order to better understand the physiopathology of adenomyosis, its onset and progression, and the interpretation of imaging signs according to the pathogenic theories.
Transvaginal ultrasound sonography. TVUS represents the first-line imaging technique to diagnose adenomyosis as it is widely available, relatively inexpensive, and very accurate if performed by expert sonographers. The sensitivity of TVUS to detect adenomyosis ranges from $65 \%$ to $81 \%$, and specificity ranges from $65 \%$ to $100 \%$. A recent meta-analysis, pooling results from eight studies, showed that two-dimensional TVUS has a sensitivity and specificity of $83.8 \%$ and $63.9 \%$, respectively, and that for three-dimensional TVUS, pooled sensitivity and specificity for all combined imaging characteristics are $88.9 \%$ and $56.0 \%$, respectively ${ }^{40}$. Recently, a uniform standardized reporting system of ultrasound findings of adenomyosis was developed by using the Morphological Uterus Sonographic Assessment (MUSA) criteria ${ }^{41}$. According to those criteria, the typical ultrasound features to consider in order to make a diagnosis of adenomyosis are described as follows: asymmetrical thickening of uterine walls, intramyometrial cysts or hyperechoic islands (or both), fan-shaped shadowing of the myometrium, myometrial echogenic subendometrial lines and buds, translesional vascularity, and irregular or interrupted JZ. However, there is little available evidence linking the ultrasound features with histopathology $y^{42,43}$, even though the different sonographic characteristics may be explained by the relative proportion of endometrial glandular structures, endometrial stroma, and hypertrophic muscle elements.

The new reporting system of adenomyosis, proposed by Van den Bosch and de Bruijn et al., includes the description of disease location (anterior, posterior, left lateral, right lateral, and fundal), classification of the lesions as focal or diffuse, presence or absence of intralesional cysts, myometrial layer involvement (JZ, myometrium, and serosal involvement), disease extent $(<25 \%$, $25 \%-50 \%$, and $>50 \%$ of uterine volume affected by adenomyosis), and lesion size ${ }^{44}$. This system would help to standardize the ultrasound description of adenomyosis; however, it has some limitations to be fully implemented in clinical practice. For example, the measurement of uterine volume affected by the disease is difficult to be objectively evaluated. Furthermore, the system needs to be validated and to be correlated with clinical findings and fertility outcomes in further studies. In fact, another major problem is the definition of severity of the disease and the identification of those features that make clinically more severe adenomyosis. Previously, Naftalin et al. showed a positive correlation between the number of ultrasound features of adenomyosis and the severity of menstrual pain, but there is no available evidence in which features are relevant from a clinical perspective ${ }^{45}$. Recently, a scoring system to define the severity of adenomyosis was proposed ${ }^{46}$; similarly, Tellum et al. developed a clinical prediction model to identify the disease by using the most relevant features ${ }^{47}$. However, those models need to be externally validated and more evidence should support their reliability.

Magnetic resonance imaging. MRI diagnosis of adenomyosis is essentially linked to the thickening of the JZ, but it also includes direct and indirect signs of the presence of endometrial glands within the myometrium and smooth muscle cell hypertrophy ${ }^{48}$. Typical adenomyosis appears as an ill-demarcated lowsignal-intensity area on T2-weighted images, representing the smooth muscle hyperplasia and the heterotopic endometrial tissue. 
T2-weighted sequences play a key role for MRI diagnosis of adenomyosis since they highlight the JZ, which has commonly increased thickness ${ }^{49}$. Furthermore, on T2-weighted MRI, small high-signal-intensity areas refer to ectopic endometrium and also small intramyometrial cysts may be detected. However, T1-weighted sequences also contribute to the diagnosis as they are useful in identifying high-signal-intensity foci representing areas of hemorrhage ${ }^{49}$. The detection of bright hemorrhagic foci has a high positive predictive value $(95 \%)$ for the diagnosis of adenomyosis but a low sensitivity $(47.5 \%)^{31}$. The common appearance of adenomyosis is an enlarged, asymmetric uterus, where adenomyotic tissue is located mainly in the posterior wall or at the fundus. The most frequent finding to diagnose adenomyosis is the thickening of JZ, and several criteria have been proposed (JZ of at least $8-12 \mathrm{~mm}$, the maximum $\mathrm{JZ} /$ total myometrium ratio of over $40 \%$, and a difference between the maximum and the minimum thickness of greater than $5 \mathrm{~mm}$ ); however, a thickness exceeding $12 \mathrm{~mm}$ seems to be highly predictive of adenomyosis ${ }^{31,50}$. Nevertheless, results are controversial as JZ may change on the basis of hormonal status (postmenopausal condition and use of hormonal contraception) and phase of menstrual cycle ${ }^{51}$. During menstruation, the uterus may present with a marked thickening of the JZ, mimicking adenomyosis; thus, MRI evaluations should preferably be performed in the late proliferative phase. Furthermore, a common pitfall to consider is caused by transient uterine contractions that can mimic either T2-weighted hypointense bands perpendicular to the JZ or focal thickening of the $\mathrm{JZ}^{52}$. In those cases, the repetition of MRI acquisition may help to differentiate a physiological condition from adenomyosis ${ }^{53}$.

A JZ of less than $8 \mathrm{~mm}$ generally allows clinicians to exclude the presence of adenomyosis ${ }^{42}$, whereas a measurement between 8 and $12 \mathrm{~mm}$ identifies the condition of adenomyosis if other criteria are present, such as maximal JZ thickness-to-myometrium thickness ratio over $40 \%$ or a relative thickening of the JZ in a localized area ${ }^{54}$. Another criterion to be considered is a difference between the maximum and the minimum thickness of the JZ measuring more than $5 \mathrm{~mm}^{54}$. However, adenomyosis may also be identified in the case of a poorly defined JZ or in the presence of linear striations of high T2 signal radiating from the endometrial zona basalis into the myometrium.

According to the most recent review on imaging of adenomyosis, MRI has a pooled sensitivity of 0.77 , specificity of 0.89 , positive likelihood ratio of 6.5 , and negative likelihood ratio of 0.2 for all subtypes, showing better results compared with those of TVUS $^{39}$. However, MRI should be considered a second-line imaging technique and should be performed by expert radiologists.

\section{Coexistence with other gynecological conditions}

Adenomyosis frequently coexists with other gynecological diseases, such as endometriosis ${ }^{25}$ and uterine fibroids ${ }^{55,56}$. In $15 \%$ to $57 \%$ of cases, uterine leiomyomas and adenomyosis coexist in the same uterus and women with both conditions are more likely to experience pelvic pain ${ }^{57}$. Results from a case-control study on women undergoing hysterectomy showed that women with leiomyoma and adenomyosis were more likely to report dysmenorrhea, dyspareunia, and non-cyclic pelvic pain compared with women with leiomyomas only $y^{3,57,58}$.

Adenomyosis and endometriosis share a number of features, so that for many years adenomyosis has been called endometriosis interna. Nevertheless, they are considered two different entities because of specific pathogenic pathways and clinical presentation, although they often coexist in the same patients. Controversial results are available from a surgical dataset showing that adenomyosis prevalence in women with endometriosis ranges from $20 \%$ to $80 \%{ }^{25,26}$. Besides, on ultrasound pre-operative assessment, $47.8 \%$ of patients undergoing surgery for DIE were affected by adenomyosis, and in those affected by both conditions, the surgical treatment was not as effective in treating pain as it was in those with only endometriosis ${ }^{59}$. Furthermore, DIE phenotype was also shown to be associated with a specific form of focal adenomyosis located in the outer myometrium ${ }^{17}$. However, larger samples of pre-operative cases are needed in order to better estimate the prevalence of gynecological comorbidities.

\section{Impact on fertility}

Adenomyosis has been considered the typical uterine condition of multiparous women, although an increasing amount of evidence suggests an association with infertility and reproductive failure $^{60-63}$. In a recent cross-sectional study on infertile women, adenomyosis prevalence were $24.4 \%$ in women at least 40 years old and $22 \%$ in women less than 40 years old. This percentage increased to $38.2 \%$ in cases of recurrent pregnancy loss and to $34.7 \%$ in previous ART failure ${ }^{21}$.

Currently, infertility is considered one of the possible clinical presentations of adenomyosis and several theories have been proposed to explain the underlying mechanisms ${ }^{7}$. Abnormal uterotubal transport seems to be an important mechanism leading to infertility and is due to anatomical distortion of the uterine cavity but also to disturbed uterine peristalsis and sperm transport ${ }^{64}$. The inner myometrium and, in particular, the JZ present with dysfunctional hyperperistalsis and increased intrauterine pressure. In addition, in the presence of adenomyosis, ultrastructural myometrial abnormalities cause a disturbance in normal myocyte contractility with subsequent loss of normal rhythmic contraction $^{65}$.

In infertile women with adenomyosis, eutopic endometrium shows a wide variety of molecular alterations, causing an altered receptivity ${ }^{13,66}$. This includes altered sex steroid hormone pathway, increased inflammatory markers and oxidative stress, reduced expression of implantation markers, lack of expression of adhesion molecules, and altered function of the gene for embryonic development (HOXA 10 gene), causing an impairment of implantation in women with adenomyosis?

There are no available studies on natural conception in adenomyosis, but several papers evaluated the effect of adenomyosis in women undergoing ART or in those surgically treated for DIE $^{67}$, and results are controversial. The meta-analysis published by Vercellini et al. in $2014{ }^{60}$ reported rates of miscarriages of $31 \%$ 
in women with adenomyosis and $14.1 \%$ in non-affected women (relative risk (RR) 2.12, 95\% confidence interval (CI) 1.20 $3.75)^{60}$. On the contrary, a case-control study in a group of women undergoing in vitro fertilization (IVF) showed that implantation rate was not significantly impaired in those diagnosed with adenomyosis at TVUS, but asymptomatic for AUB, compared to those not affected by the disease ${ }^{68}$. On the contrary, Mavrelos et $a l .{ }^{69}$, in a multicenter prospective study, showed that the estimated probability of clinical pregnancy decreased from $42.7 \%$ in women with no adenomyosis to $22.9 \%$ in those with four and $13.0 \%$ in those with all seven ultrasound features of adenomyosis. This suggests that the severity of the condition, expressed as a number of morphological features on ultrasound, worsens the reproductive outcome. Results from the most recent systematic review and meta-analysis on IVF treatment outcomes in adenomyosis, including 11 studies and 519 patients with TVUS or MRI diagnosis of adenomyosis, confirmed the detrimental effect of the uterine disease on reproductive outcome ${ }^{61}$. Rates of implantation, clinical pregnancy per cycle, clinical pregnancy per embryo transfer, ongoing pregnancy, and live-birth rate among women with adenomyosis were significantly reduced, whereas miscarriage rate was increased. The study also demonstrated that a preIVF treatment with the use of gonadotropin-releasing hormone analogue (GnRHa) down-regulation may be beneficial to the pregnancy rate ${ }^{61}$.

Concerning the association between endometriosis and adenomyosis and fertility, results from a systematic review and metaanalysis published in 2014 on women after surgery for rectovaginal and colorectal endometriosis reported a $68 \%$ reduction in the likelihood of pregnancy in women who wanted to become pregnant $^{70}$. In a recent retrospective cohort of women undergoing IVF, the presence of adenomyosis affected clinical pregnancy rate, live-birth rate and miscarriage rate. In particular, compared with women with endometriosis alone, those affected by adenomyosis had a significantly lower clinical pregnancy rate $(26.4 \%$ versus $12.5 \%)$ and live-birth rate $(26.4 \%$ versus $12.5 \%)$. Similar results were reported in women with endometriosis and adenomyosis ${ }^{71}$.

All of this evidence supported a negative effect of adenomyosis on reproductive outcome; however, it is essential to define strict criteria for imaging diagnosis and classification of adenomyosis in order to design and then compare homogeneous studies. This would allow clinicians to evaluate whether the severity and extent of disease have an additional negative effect and determine the therapeutic options to improve fertility in patients with adenomyosis.

\section{Impact on pregnancy outcome}

Adenomyosis is considered a reproductive disorder and an increasing number of papers are showing that not only fertility but also pregnancy outcome is affected. Given late pregnancy outcomes, an increased risk of preterm birth (PTB) (adjusted odds ratio [aOR] $1.84,95 \% \mathrm{CI} 1.32-4.31$ ) and preterm premature rupture of membranes (aOR 1.98, 95\% CI 1.39-3.15) in patients with adenomyosis was shown ${ }^{72}$. These results were confirmed in a small cohort of women diagnosed by ultrasound or MRI before pregnancy, showing also a significantly higher risk of cesarean delivery (OR 4.5, 95\% CI 2.1-9.7), small for gestational age (SGA) fetuses (OR 4.3, 95\% CI 1.8-10.3), postpartum hemorrhage (OR 6.5, 95\% CI 2.2-19.0), and fetal malpresentation (OR 4.2, 95\% CI 1.6-10.8) $)^{73}$. Furthermore, a recent retrospective case-control study reported that adenomyosis is also associated with increased risk of second-trimester miscarriage (OR 11.2, 95\% CI 2.2-71.2), pre-eclampsia (OR 21.0, 95\% CI 4.8-124.5), and placental malposition (OR 4.9, 95\% CI 1.4-16.3) 74 $^{\text {The type }}$ of adenomyosis may influence the pregnancy outcome, as shown by the higher rates of pregnancy-induced hypertension and uterine infection in patients with diffuse-type adenomyosis than in patients with focal-type adenomyosis. In addition, as found in the same study, the rates of cervical incompetency increased according to the extent of adenomyosis ${ }^{75}$. Very recently, a prospective Japanese nationwide birth cohort study was published, and according to results obtained from self-reported questionnaires, adenomyosis was a risk factor for PTB of less than 37 weeks (aOR $2.49,95 \%$ CI 1.89-3.41), PTB of less than 34 weeks (aOR 1.91, 95\% CI 1.02-3.55), low birth weight of less than $2500 \mathrm{~g}$ (aOR $1.83,95 \%$ CI 1.36-2.45), low birth weight of less than $1500 \mathrm{~g} \mathrm{(aOR}$ 2.39 , 95\% CI 1.20-4.77), and SGA neonates (aOR 1.68, 95\% CI $1.13-2.51)^{76}$.

Concerning the pathogenic mechanisms involved in obstetric complications in adenomyosis, the role of inflammation, increased myometrial prostaglandin production, altered uterine contractility, and intrauterine pressure was hypothesized to explain the link with $\mathrm{PTB}^{77}$. In adenomyosis, an activation of local and systemic inflammatory pathways was shown, influencing the decidua-trophoblast interactions early in gestation as well as chorion-decidua interactions that could activate mechanisms of PTB later in pregnancy ${ }^{77}$. In regard to the increased rate of placenta-related disorders, the defective myometrial spiral artery remodeling and deep placentation can be considered to be among the major causes of obstetrical syndromes in adenomyosis. In fact, alterations in the inner myometrium and in the uterine $\mathrm{JZ}$ have been well documented ${ }^{12,78}$. However, further research protocols are needed from both the epidemiological and physiopathological point of view. In fact, well-conducted studies may be performed only if uniform and shared imaging diagnostic criteria and classification are used to make the pre-pregnancy diagnosis of adenomyosis. Similarly, the lack of evidence on molecular mechanisms leading to obstetric complications in adenomyosis should be filled.

\section{Management of adenomyosis}

Adenomyosis has a negative impact on women's quality of life in a high percentage of cases because of AUB and pain requiring a lifelong management plan through medical or surgical treatment $^{79}$. The choice depends on the woman's age, reproductive status, and clinical symptoms. However, so far, few clinical studies focusing on medical or surgical treatment for adenomyosis have been performed, and no drugs labelled for adenomyosis are currently available ${ }^{8}$. Nonetheless, the disease is increasingly diagnosed in young women with reproductive desire, and conservative treatments should be preferred. 
The surgical approach remains a controversial subject ${ }^{80}$, but minimally invasive surgical treatments should be performed in specific cases, informing the patient about the potential risks in case of pregnancy. Conservative surgical options include endometrial ablation, hysteroscopic endometrial and adenomyoma resection, laparoscopic resection of adenomyosis, high-intensity focused ultrasonography, and uterine artery embolization ${ }^{81}$. However, robust evidence supporting conservative surgical treatments of adenomyosis is still lacking.

According to pathogenic mechanisms, several medical hormonal and non-hormonal treatments are used off-label to manage pain and bleeding and to improve fertility outcome. The use of GnRHa is indicated before fertility treatments to improve the chances of pregnancy in infertile women with adenomyosis ${ }^{61}$, and the highest pregnancy rate is reported in those undergoing frozen embryo transfer after GnRHa pre-treatment ${ }^{82}$. In contrast, the use of GnRHa for pain and bleeding should be considered only for short-term treatment because of menopausal effects.

The use of progestins is supported by the anti-proliferative and anti-inflammatory effect and decidualization and then atrophy of endometrial tissue, causing a significant reduction in bleeding $^{8}$. Among progestins, norethisterone acetate (NETA), vaginal danazol, and dienogest (DNG) may be considered. Recently, a randomized, double-blind, multicenter, placebo-controlled trial on DNG, daily administered for 16 weeks in women with adenomyosis, showed a significant decrease of pain score in those treated $^{83}$. The results were confirmed in a long-term treatment study, demonstrating good tolerability and a reduction in pain and higher quality-of-life scores ${ }^{84}$. The levonorgestrel-releasing intrauterine system (LNG-IUS) is also an effective, reversible, and long-term treatment used successfully to treat adenomyosis. Results show that it reduces menstrual bleeding, pain, and uterine volume and has an overall satisfaction of $72 \%$. However, new drugs, such as selective progesterone receptor modulators, aromatase inhibitors, valproic acid, and anti-platelet therapy, are under development for the treatment of adenomyosis ${ }^{8}$.

\section{Conclusions}

In the last decade, a significant improvement has been achieved in understanding and management of adenomyosis. Adenomyosis has become a clinical entity rather than just a histological diagnosis and it can be identified through non-invasive imaging techniques. An increasing amount of evidence is showing the pathogenic mechanisms involved and the potential medical treatments. However, there is still the urgent need for a uniform and shared diagnostic criteria profile and reporting system, in both imaging and histology, in order to identify all of the clinical and imaging phenotypes of adenomyosis. This is the first step to share a common language among scientists and clinicians, who would share the same diagnostic criteria. This would allow clinicians to design and perform methodologically well-conducted prospective studies on adenomyosis prevalence, gynecological comorbidities, effectiveness of medical or surgical treatments, and impact on fertility and pregnancy outcome.

\section{Abbreviations}

aOR, adjusted odds ratio; ART, assisted reproductive technology; AUB, abnormal uterine bleeding; CI, confidence interval; DIE, deep infiltrating endometriosis; DNG, dienogest; FOAM, focal adenomyosis of the outer myometrium; GnRHa, gonadotropin-releasing hormone analogues; HMB, heavy menstrual bleeding; IVF, in vitro fertilization; JZ, junctional zone; MRI, magnetic resonance imaging; OR, odds ratio; PTB, preterm birth; $\mathrm{RR}$, relative risk; SGA, small for gestational age; TIAR, tissue injury and repair; TVUS, transvaginal ultrasonography.

\section{Grant information}

The author(s) declared that no grants were involved in supporting this work.
1. McCluggage WG, Robboy SJ: Mesenchymal uterine tumors, other than pure smooth muscle neoplasms, and adenomyosis. In: Robboy SJ, Mutter GL, Prat $\mathrm{J}$, et al.: (eds), editor. Robboy's pathology of the female reproductive tract (second edition). Churchill Livingstone Elsevier, London, UK; 2009; 427-56. Reference Source

2. Peric H, Fraser IS: The symptomatology of adenomyosis. Best Pract Res Clin Obstet Gynaecol. 2006; 20(4): 547-55. PubMed Abstract | Publisher Full Text

3. Taran FA, Wallwiener M, Kabashi D, et al:: Clinical characteristics indicating adenomyosis at the time of hysterectomy: a retrospective study in 291 patients. Arch Gynecol Obstet. 2012; 285(6): 1571-6. PubMed Abstract | Publisher Full Text

4. Pinzauti S, Lazzeri L, Tosti C, et al:: Transvaginal sonographic features of diffuse adenomyosis in 18-30-year-old nulligravid women without endometriosis: association with symptoms. Ultrasound Obstet Gynecol. 2015; 46(6): 730-6.

PubMed Abstract | Publisher Full Text

5. F Van den Bosch T, Van Schoubroeck D: Ultrasound diagnosis of endometriosis and adenomyosis: State of the art. Best Pract Res Clin Obstet Gynaecol. 2018; 51: 16-24.

PubMed Abstract | Publisher Full Text | F1000 Recommendation
6. Leyendecker G, Bilgicyildirim A, Inacker M, et al:: Adenomyosis and endometriosis. Re-visiting their association and further insights into the mechanisms of auto-traumatisation. An MRI study. Arch Gynecol Obstet. 2015; 291(4): 917-32.

PubMed Abstract | Publisher Full Text | Free Full Text

7. Vannuccini S, Tosti C, Carmona F, et al:: Pathogenesis of adenomyosis: an update on molecular mechanisms. Reprod Biomed Online. 2017; 35(5): 592-601. PubMed Abstract | Publisher Full Text

8. Vannuccini S, Luisi S, Tosti C, et al.: Role of medical therapy in the management of uterine adenomyosis. Fertil Steril. 2018; 109(3): 398-405. PubMed Abstract | Publisher Full Text

9. Carrarelli P, Yen CF, Arcuri F, et al:: Myostatin, follistatin and activin type Il receptors are highly expressed in adenomyosis. Fertil Steril. 2015; 104(3): receptors

Pub-52.e1.

10. Carrarelli $\mathrm{P}$, Yen CF, Funghi $\mathrm{L}$, et al:: Expression of Inflammatory and Neurogenic Mediators in Adenomyosis. Reprod Sci. 2016; 24(3): 369-75. PubMed Abstract | Publisher Full Text

11. F García-Solares J, Donnez J, Donnez O, et al.: Pathogenesis of uterine adenomyosis: invagination or metaplasia? Fertil Steril. 2018; 109(3): 371-9. PubMed Abstract | Publisher Full Text | F1000 Recommendation 
12. Brosens I, Derwig I, Brosens J, et al.: The enigmatic uterine junctional zone: the missing link between reproductive disorders and major obstetrical disorders? Hum Reprod. 2010; 25(3): 569-74.

PubMed Abstract | Publisher Full Text

13. Benagiano G, Brosens I, Habiba M: Structural and molecular features of the endomyometrium in endometriosis and adenomyosis. Hum Reprod Update. 2014; 20(3): 386-402.

PubMed Abstract | Publisher Full Text

14. Shaked S, Jaffa AJ, Grisaru D, et al:: Uterine peristalsis-induced stresses within the uterine wall may sprout adenomyosis. Biomech Model Mechanobiol. 2015; 14(3): 437-44.

PubMed Abstract | Publisher Full Text

15. F Gargett CE, Schwab KE, Deane JA: Endometrial stem/progenitor cells: the first 10 years. Hum Reprod Update. 2016; 22(2): 137-63.

PubMed Abstract | Publisher Full Text | Free Full Text | F1000 Recommendation

16. Chan RW, Schwab KE, Gargett CE: Clonogenicity of human endometrial epithelial and stromal cells. Biol Reprod. 2004; 70(6): 1738-50. PubMed Abstract | Publisher Full Text

17. Chapron C, Tosti C, Marcellin L, et al:: Relationship between the magnetic resonance imaging appearance of adenomyosis and endometriosis phenotypes. Hum Reprod. 2017; 32(7): 1393-401.

PubMed Abstract | Publisher Full Text

18. F Marcellin L, Santulli P, Bortolato S, et al:: Anterior Focal Adenomyosis and Bladder Deep Infiltrating Endometriosis: Is There a Link? J Minim Invasive Gynecol. 2018; 25(5): 896-901.

PubMed Abstract | Publisher Full Text | F1000 Recommendation

19. Vercellini $P$, Viganò $P$, Somigliana $E$, et al.: Adenomyosis: epidemiological factors. Best Pract Res Clin Obstet Gynaecol. 2006; 20(4): 465-77. PubMed Abstract | Publisher Full Text

20. Li X, Liu X, Guo SW: Clinical profiles of 710 premenopausal women with adenomyosis who underwent hysterectomy. J Obstet Gynaecol Res. 2014; 40(2): 485-94.

PubMed Abstract | Publisher Full Text

21. F Puente JM, Fabris A, Patel J, et al:: Adenomyosis in infertile women: prevalence and the role of 3D ultrasound as a marker of severity of the disease. Reprod Biol Endocrinol. 2016; 14(1): 60.

PubMed Abstract | Publisher Full Text | Free Full Text | F1000 Recommendation

22. F Naftalin J, Hoo W, Pateman $\mathrm{K}$, et al:: Is adenomyosis associated with menorrhagia? Hum Reprod. 2014; 29(3): 473-9.

PubMed Abstract | Publisher Full Text | F1000 Recommendation

23. F Abbott JA: Adenomyosis and Abnormal Uterine Bleeding (AUB-A)Pathogenesis, diagnosis, and management. Best Pract Res Clin Obstet Gynaecol. 2017; 40: 68-81.

PubMed Abstract | Publisher Full Text | F1000 Recommendation

24. Munro MG, Critchley HO, Broder MS, et al: FIGO classification system (PALMCOEIN) for causes of abnormal uterine bleeding in nongravid women of reproductive age. Int J Gynaecol Obstet. 2011; 113(1): 3-13. PubMed Abstract | Publisher Full Text

25. F Di Donato N, Montanari G, Benfenati A, et al:: Prevalence of adenomyosis in women undergoing surgery for endometriosis. Eur J Obstet Gynecol Reprod Biol. 2014; 181: 289-93

PubMed Abstract | Publisher Full Text | F1000 Recommendation

26. F Eisenberg VH, Arbib N, Schiff E, et al:: Sonographic Signs of Adenomyosis Are Prevalent in Women Undergoing Surgery for Endometriosis and May Suggest a Higher Risk of Infertility. Biomed Res Int. 2017; 2017: 8967803. PubMed Abstract | Publisher Full Text | Free Full Text | F1000 Recommendation

27. F Naftalin J, Hoo W, Pateman $\mathrm{K}$, et al: How common is adenomyosis? A prospective study of prevalence using transvaginal ultrasound in a gynaecology clinic. Hum Reprod. 2012; 27(12): 3432-9. PubMed Abstract | Publisher Full Text | F1000 Recommendation

28. Yeniel O, Cirpan T, Ulukus M, et al.: Adenomyosis: prevalence, risk factors, symptoms and clinical findings. Clin Exp Obstet Gynecol. 2007; 34(3): 163-7. PubMed Abstract

29. Bergholt $\mathrm{T}$, Eriksen $\mathrm{L}$, Berendt $\mathrm{N}$, et al.: Prevalence and risk factors of adenomyosis at hysterectomy. Hum Reprod. 2001; 16(11): 2418-21. PubMed Abstract | Publisher Full Text

30. Weiss G, Maseelall P, Schott LL, et al.: Adenomyosis a variant, not a disease? Evidence from hysterectomized menopausal women in the Study of Women's Health Across the Nation (SWAN). Fertil Steril. 2009; 91(1): 201-6. PubMed Abstract | Publisher Full Text | Free Full Text

31. Bazot M, Cortez A, Darai E, et al:: Ultrasonography compared with magnetic resonance imaging for the diagnosis of adenomyosis: correlation with histopathology. Hum Reprod. 2001; 16(11): 2427-33. PubMed Abstract | Publisher Full Text

32. Uduwela AS, Perera MA, Aiqing L, et al:: Endometrial-myometrial interface: relationship to adenomyosis and changes in pregnancy. Obstet Gynecol Surv. 2000; 55(6): 390-400.

PubMed Abstract | Publisher Full Text

33. Vercellini P, Ragni G, Trespidi L, et al.: Adenomyosis: a déjà vu? Obstet Gynecol
Surv. 1993; 48(12): 789-94.

PubMed Abstract | Publisher Full Tex

34. Zaloudek CJ, Hendrickson MR, Soslow RA: Mesenchymal tumors of the uterus. In: In Kurman RJ, Ellenson LH RB (eds), editor. Blaustein's pathology of the female genital tract (sixth edition). Sixth edit. New-York, NY: Springer Science; 2011; 453-528. Publisher Full Text

35. Nucci MR, Quade BJ: Uterine mesenchymal tumors. In: Crum CP, Nucci MR, Le KR (eds), Diagnostic gynecology and obstetric pathology (second edition). Saunders Elsevier, Philadelphia, PA, 2011; 582-639.

36. Bird CC, McElin TW, Manalo-Estrella P: The elusive adenomyosis of the uterus-revisited. Am J Obstet Gynecol. 1972; 112(5): 583-93.

PubMed Abstract | Publisher Full Text

37. Kishi $\mathrm{Y}$, Suginami $\mathrm{H}$, Kuramori R, et al:: Four subtypes of adenomyosis assessed by magnetic resonance imaging and their specification. Am J Obstet Gynecol. 2012; 207(2): 114.e1-7.

PubMed Abstract | Publisher Full Text

38. Grimbizis GF, Mikos T, Tarlatzis B: Uterus-sparing operative treatment for adenomyosis. Fertil Steril. 2014; 101(2): 472-87. PubMed Abstract | Publisher Full Text

39. $\mathrm{F}$ Bazot $\mathrm{M}$, Daraï $\mathrm{E}$ : Role of transvaginal sonography and magnetic resonance imaging in the diagnosis of uterine adenomyosis. Fertil Steril. 2018; 109(3): 389-97.

PubMed Abstract | Publisher Full Text | F1000 Recommendation

40. F Andres MP, Borrelli GM, Ribeiro J, et al.: Transvaginal Ultrasound for the Diagnosis of Adenomyosis: Systematic Review and Meta-Analysis. J Minim Invasive Gynecol. 2018; 25(2): 257-64.

PubMed Abstract | Publisher Full Text | F1000 Recommendation

41. Van den Bosch T, Dueholm M, Leone FP, et al:: Terms, definitions and measurements to describe sonographic features of myometrium and uterine masses: a consensus opinion from the Morphological Uterus Sonographic Assessment (MUSA) group. Ultrasound Obstet Gynecol. 2015; 46(3): 284-98. PubMed Abstract | Publisher Full Text

42. Reinhold C, Tafazoli F, Mehio A, et al:: Uterine adenomyosis: endovaginal US and MR imaging features with histopathologic correlation. Radiographics. 1999; 19 Spec No: S147-60.

PubMed Abstract | Publisher Full Text

43. F Vandermeulen L, Cornelis A, Kjaergaard Rasmussen C, et al:: Guiding histological assessment of uterine lesions using 3D in vitro ultrasonography and stereotaxis. Facts Views Vis Obgyn. 2017; 9(2): 77-84. PubMed Abstract | Free Full Text | F1000 Recommendation

44. F Van den Bosch T, de Bruijn AM, de Leeuw RA, et al:: A sonographic classification and reporting system for diagnosing adenomyosis. Ultrasound Obstet Gynecol. 2018.

PubMed Abstract | Publisher Full Text | F1000 Recommendation

45. Naftalin J, Hoo W, Nunes N, et al:: Association between ultrasound features of adenomyosis and severity of menstrual pain. Ultrasound Obstet Gynecol. 2016; 47(6): 779-83.

PubMed Abstract | Publisher Full Tex

46. F Lazzeri L, Morosetti G, Centini G, et al:: A sonographic classification of adenomyosis: interobserver reproducibility in the evaluation of type and degree of the myometrial involvement. Fertil Steril. 2018; 110(6): 1154-1161.e3. PubMed Abstract | Publisher Full Text | F1000 Recommendation

47. F Tellum T, Nygaard S, Skovholt EK, et al.: Development of a clinical prediction model for diagnosing adenomyosis. Fertil Steril. 2018; 110(5): 957-964.e3. PubMed Abstract | Publisher Full Text | F1000 Recommendation

48. Exacoustos $C$, Manganaro $L$, Zupi E: Imaging for the evaluation of endometriosis and adenomyosis. Best Pract Res Clin Obstet Gynaecol. 2014; 28(5): 655-81. PubMed Abstract | Publisher Full Text

49. F Agostinho L, Cruz R, Osório F, et al:: MRI for adenomyosis: a pictorial review. Insights Imaging. 2017; 8(6): 549-56.

PubMed Abstract | Publisher Full Text | Free Full Text | F1000 Recommendation

50. Champaneria $\mathrm{R}$, Abedin $\mathrm{P}$, Daniels $\mathrm{J}$, et al.: Ultrasound scan and magnetic resonance imaging for the diagnosis of adenomyosis: systematic review comparing test accuracy. Acta Obstet Gynecol Scand. 2010; 89(11): 1374-84. PubMed Abstract | Publisher Full Tex

51. Novellas S, Chassang M, Delotte J, et al.: MRI characteristics of the uterine junctional zone: From normal to the diagnosis of adenomyosis. AJR Am J Roentgenol. 2011; 196(5): 1206-13.

PubMed Abstract | Publisher Full Text

52. Togashi K, Kawakami S, Kimura I, et al.: Uterine contractions: possible diagnostic pitfall at MR imaging. J Magn Reson Imaging. 1993; 3(6): 889-93. PubMed Abstract | Publisher Full Text

53. Tamai $\mathrm{K}$, Togashi $\mathrm{K}$, Ito $\mathrm{T}$, et al:: MR imaging findings of adenomyosis: correlation with histopathologic features and diagnostic pitfalls. Radiographics. 2005; 25(1): 21-40.

PubMed Abstract | Publisher Full Text

54. Dueholm M, Lundorf E, Hansen ES, et al:: Magnetic resonance imaging and transvaginal ultrasonography for the diagnosis of adenomyosis. Fertil Steri. 2001; 76(3): 588-94

PubMed Abstract | Publisher Full Text 
55. Brucker SY, Huebner M, Wallwiener M, et al.: Clinical characteristics indicating adenomyosis coexisting with leiomyomas: a retrospective, questionnairebased study. Fertil Steril. 2014; 101(1): 237-241.e1. PubMed Abstract | Publisher Full Text

56. Taran F, Stewart E, Brucker S: Adenomyosis: Epidemiology, Risk Factors, Clinical Phenotype and Surgical and Interventional Alternatives to Hysterectomy. Geburtshilfe Frauenheilkd. 2013; 73(9): 924-31. PubMed Abstract | Publisher Full Text | Free Full Text

57. Taran FA, Weaver AL, Coddington CC, et al:: Characteristics indicating adenomyosis coexisting with leiomyomas: a case-control study. Hum Reprod. 2010; 25(5): 1177-82

PubMed Abstract | Publisher Full Text | Free Full Text

58. Boeer B, Wallwiener M, Rom J, et al:: Differences in the clinical phenotype of adenomyosis and leiomyomas: a retrospective, questionnaire-based study Arch Gynecol Obstet. 2014; 289(6): 1235-9.

PubMed Abstract | Publisher Full Text

59. Lazzeri L, Di Giovanni A, Exacoustos C, et al:: Preoperative and Postoperative Clinical and Transvaginal Ultrasound Findings of Adenomyosis in Patients With Deep Infiltrating Endometriosis. Reprod Sci. 2014; 21(8): 1027-33. PubMed Abstract | Publisher Full Text

60. Vercellini $\mathrm{P}$, Consonni $\mathrm{D}$, Dridi $\mathrm{D}$, et al.: Uterine adenomyosis and in vitro fertilization outcome: a systematic review and meta-analysis. Hum Reprod. 2014; 29(5): 964-77.

PubMed Abstract | Publisher Full Text

61. F Younes G, Tulandi T: Effects of adenomyosis on in vitro fertilization treatment outcomes: a meta-analysis. Fertil Steril. 2017; 108(3): 483-490.e3. PubMed Abstract | Publisher Full Text | F1000 Recommendation

62. Tomassetti C, Meuleman C, Timmerman D, et al:: Adenomyosis and subfertility: evidence of association and causation. Semin Reprod Med. 2013; 31(2): 101-8. PubMed Abstract | Publisher Full Text

63. Campo S, Campo V, Benagiano G: Adenomyosis and infertility. Reprod Biomed Online. 2012; 24(1): 35-46.

PubMed Abstract | Publisher Full Text

64. F Harada $\mathrm{T}$, Khine YM, Kaponis $\mathrm{A}$, et al:: The Impact of Adenomyosis on Women's Fertility. Obstet Gynecol Surv. 2016; 71(9): 557-68.

PubMed Abstract | Publisher Full Text | Free Full Text | F1000 Recommendation

65. Mehasseb MK, Bell SC, Pringle JH, et al: Uterine adenomyosis is associated with ultrastructural features of altered contractility in the inner myometrium. Fertil Steril. 2010; 93(7): 2130-6. PubMed Abstract | Publisher Full Text

66. F Yen CF, Huang SJ, Lee CL, et al:: Molecular Characteristics of the Endometrium in Uterine Adenomyosis and Its Biochemical Microenvironment. Reprod Sci. 2017; 24(10): 1346-61.

PubMed Abstract | Publisher Full Text | F1000 Recommendation

67. F Dueholm M: Uterine adenomyosis and infertility, review of reproductive outcome after in vitro fertilization and surgery. Acta Obstet Gynecol Scand. 2017; 96(6): 715-26.

PubMed Abstract | Publisher Full Text | F1000 Recommendation

68. Benaglia L, Cardellicchio L, Leonardi M, et al.: Asymptomatic adenomyosis and embryo implantation in IVF cycles. Reprod Biomed Online. 2014; 29(5): 606-11. PubMed Abstract | Publisher Full Text

69. F Mavrelos D, Holland TK, O'Donovan O, et al:: The impact of adenomyosis on the outcome of IVF-embryo transfer. Reprod Biomed Online. 2017; 35(5): 549-54.

PubMed Abstract | Publisher Full Text | F1000 Recommendation

70. F Vercellini P, Consonni D, Barbara G, et al:: Adenomyosis and reproductive performance after surgery for rectovaginal and colorectal endometriosis: a systematic review and meta-analysis. Reprod Biomed Online. 2014; 28(6): 704-13.

PubMed Abstract | Publisher Full Text | F1000 Recommendation

71. F Sharma S, Bathwal S, Agarwal N, et al.: Does presence of adenomyosis affect reproductive outcome in IVF cycles? A retrospective analysis of 973 patients. Reprod Biomed Online. 2019; 38(1): 13-21.

PubMed Abstract | Publisher Full Text | F1000 Recommendation

72. F Juang CM, Chou P, Yen MS, et al: Adenomyosis and risk of preterm delivery. BJOG. 2007; 114(2): 165-9.

PubMed Abstract | Publisher Full Text | F1000 Recommendation

73. Mochimaru A, Aoki S, Oba MS, et al:: Adverse pregnancy outcomes associated with adenomyosis with uterine enlargement. J Obstet Gynaecol Res. 2015 41(4): 529-33.

PubMed Abstract | Publisher Full Text

74. $\mathrm{F}$ Hashimoto A, Iriyama T, Sayama S, et al.: Adenomyosis and adverse perinatal outcomes: increased risk of second trimester miscarriage, preeclampsia, and placental malposition. J Matern Fetal Neonatal Med. 2018; 31(3): 364-9.

PubMed Abstract | Publisher Full Text | F1000 Recommendation

75. $\mathrm{F}$ Tamura $\mathrm{H}$, Kishi $\mathrm{H}$, Kitade $\mathrm{M}$, et al:: Complications and outcomes of pregnant women with adenomyosis in Japan. Reprod Med Biol. 2017; 16(4): 330-6.

PubMed Abstract | Publisher Full Text | Free Full Text | F1000 Recommendation

76. F Yamaguchi A, Kyozuka H, Fujimori K, et al:: Risk of preterm birth, low birthweight and small-for-gestational-age infants in pregnancies with adenomyosis: A cohort study of the Japan Environment and Children's Study. Acta Obstet Gynecol Scand. 2019; 98(3): 359-364.

PubMed Abstract | Publisher Full Text | F1000 Recommendation

77. Vannuccini S, Clifton VL, Fraser IS, et al.: Infertility and reproductive disorders: impact of hormonal and inflammatory mechanisms on pregnancy outcome. Hum Reprod Update. 2016; 22(1): 104-15.

PubMed Abstract | Publisher Full Text

78. Brosens I, Pijnenborg R, Benagiano G: Defective myometrial spiral artery remodelling as a cause of major obstetrical syndromes in endometriosis and adenomyosis. Placenta. 2013; 34(2): 100-5. PubMed Abstract | Publisher Full Text

79. Tosti $C$, Troìa L, Vannuccini $\mathrm{S}$, et al.: Current and future medical treatment of adenomyosis. JE. 2016; 8: 127-35. Publisher Full Text

80. F Osada $\mathrm{H}$ : Uterine adenomyosis and adenomyoma: the surgical approach. Fertil Steril. 2018; 109(3): 406-17. PubMed Abstract | Publisher Full Text | F1000 Recommendation

81. F Dueholm M: Minimally invasive treatment of adenomyosis. Best Pract Res Clin Obstet Gynaecol. 2018; 51: 119-37. PubMed Abstract | Publisher Full Text | F1000 Recommendation

82. F Park CW, Choi MH, Yang KM, et al:: Pregnancy rate in women with adenomyosis undergoing fresh or frozen embryo transfer cycles following gonadotropin-releasing hormone agonist treatment. Clin Exp Reprod Med. 2016; 43(3): 169-73

PubMed Abstract | Publisher Full Text | Free Full Text | F1000 Recommendation

83. F Osuga $Y$, Fujimoto-Okabe $\mathrm{H}$, Hagino A: Evaluation of the efficacy and safety of dienogest in the treatment of painful symptoms in patients with adenomyosis: a randomized, double-blind, multicenter, placebo-controlled study. Fertil Steril. 2017; 108(4): 673-8.

PubMed Abstract | Publisher Full Text | F1000 Recommendation

84. $\mathrm{F}$ Osuga $\mathrm{Y}$, Watanabe $\mathrm{M}$, Hagino A: Long-term use of dienogest in the treatment of painful symptoms in adenomyosis. J Obstet Gynaecol Res. 2017; 43(9): 1441-8

PubMed Abstract | Publisher Full Text | F1000 Recommendation

85. Sheng J, Zhang WY, Zhang JP, et al:: The LNG-IUS study on adenomyosis: a 3-year follow-up study on the efficacy and side effects of the use of levonorgestrel intrauterine system for the treatment of dysmenorrhea associated with adenomyosis. Contraception. 2009; 79(3): 189-93. PubMed Abstract | Publisher Full Text 


\section{Open Peer Review}

\section{Current Peer Review Status:}

\section{Editorial Note on the Review Process}

Faculty Reviews are review articles written by the prestigious Members of Faculty Opinions. The articles are commissioned and peer reviewed before publication to ensure that the final, published version is comprehensive and accessible. The reviewers who approved the final version are listed with their names and affiliations.

\section{The reviewers who approved this article are:}

\section{Version 1}

\section{Peng-Hui Wang}

1 Department of Obstetrics and Gynecology, National Yang-Ming University School of Medicine, Taipei, Taiwan

2 Department of Obstetrics and Gynecology, Taipei Veterans General Hospital, Taipei, Taiwan Competing Interests: No competing interests were disclosed.

\section{Davor Jurkovic} Institute for Women's Health, University College Hospital, London, UK Competing Interests: No competing interests were disclosed.

The benefits of publishing with F1000Research:

- Your article is published within days, with no editorial bias

- You can publish traditional articles, null/negative results, case reports, data notes and more

- The peer review process is transparent and collaborative

- Your article is indexed in PubMed after passing peer review

- Dedicated customer support at every stage

For pre-submission enquiries, contact research@f1000.com 